\title{
GLOBAL SUSHI: THE POLITICAL ECONOMY OF THE MEDITERRANEAN BLUEFIN TUNA FISHERY IN THE MODERN ERA
}

\author{
Stefano B. Longo \\ Department of Sociology and Anthropology \\ East Tennessee State University \\ sblongo@gmail.com
}

\begin{abstract}
The bluefin tuna fishery in the Mediterranean has a long history of human interaction. In recent times, this fishery has become the central source of bluefin tuna for core nations, particularly Japan. This process was set off in large part by the growth of global fish markets, driven by the valuable sushi and sashimi market, and overfishing of other bluefin stocks in other parts of the world. The transformation of this fishery from an artisanal trap fishery to a globalized industrial fishery has had a number of social and environmental consequences. Based on in-depth fieldwork and historical research, this paper examines the political economy of the bluefin tuna fishery in the Mediterranean, with a focus on Sicily. It provides a descriptive history of the changing conditions in this fishery, paying special attention to the modern fishery. This research contributes to the discussions regarding the globalization and industrialization of agri-food systems and environmental degradation.
\end{abstract}

\section{INTRODUCTION}

The Mediterranean bluefin tuna fishery has a long and rich history. Human civilizations have been interacting with this fishery for millennia, during which it has been an important source of protein for regional populations. While early Mediterranean civilizations had rudimentary forms of capture technology, by the turn of the first millennium CE, a sophisticated bluefin tuna trap fishery ${ }^{1}$ emerged (Consolo 1986). This trap fishery, called tonnara in Italian, madrague in French, almadraba in Spanish, and armação in Portuguese, forms an elaborate maze of nets that capture and corral bluefin tuna during their spawning season. Active for more than a thousand years, the traditional/artisanal bluefin tuna trap fishery has experienced a collapsed in the Mediterranean and has struggled where it is still practiced.

The modern processes of capitalist globalization and industrialization are impacting fishing communities throughout the world. This paper examines the serious social and ecological consequences in the Mediterranean bluefin fishery. Recent heavy fishing pressure on bluefin tuna stocks in the Atlantic and Mediterranean have had profound effects. In a period of a few decades,

\footnotetext{
${ }^{1}$ In this paper, the traditional trap fishery is distinguished from the broader Mediterranean fishery, which includes modern methods of fishing (e.g. purse-seine and long-line) and their ensuing industries. Although the trap fishery is still part of modern production in some parts of the Mediterranean, it is a unique practice and culture of fishing that is distinct from the modern industrial fishery.
} 
the broader Mediterranean bluefin fishery has been transformed from an artisanal, mostly regional, fishery, into a capital and technology intensive fishery that primarily serves the global sushi and sashimi market.

Figure1: Map of the Mediterranean Basin (IAM 1998)

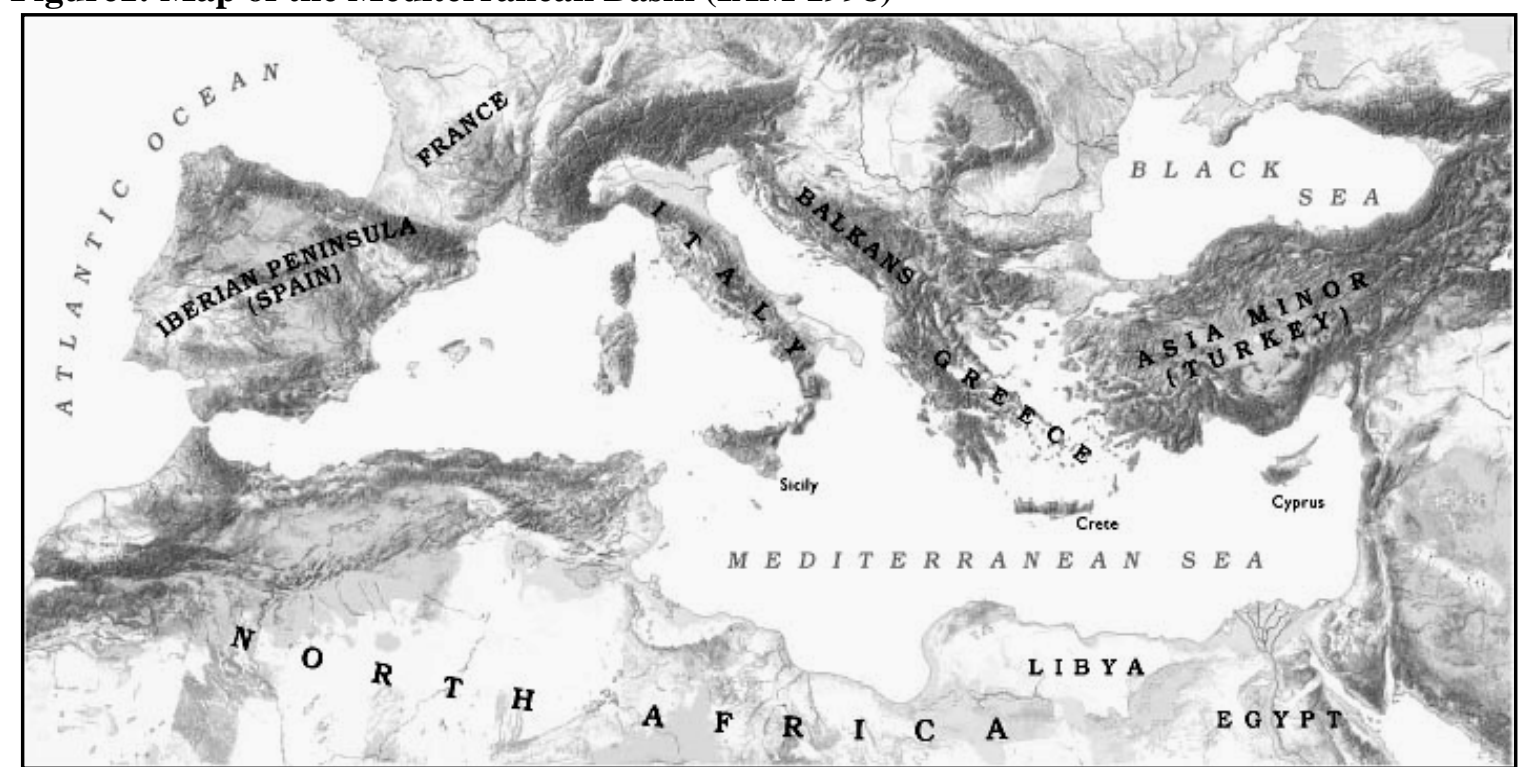

This examination will be considered using a political-economic approach and is based on historical research and fieldwork done in Sicily, Italy during 2007 and 2008. Fieldwork consisted of observations and in-depth interviews with traditional/artisanal trap fishers, individuals associated with the modern fishing industry, as well as community members and political figures. Historical research was conducted in local and regional libraries, as well as utilizing the personal archives and libraries of participants. Finally, public statistics and industry sources were accessed to provide descriptive quantitative data. Hence, this work can be considered "structural fieldwork," which "is most interested in understanding structures of power that provide much of the logic by which political and economic life is organized" (Gellert and Shefner 2009: 196)

\section{ENVIRONMENTAL SOCIOLOGY AND POLITICAL ECONOMY: AN ECO- STRUCTURAL FRAMEWORK}

Incorporating the many disciplines within the social sciences, political economic studies provide a broad point of view when analyzing the social world. Simultaneously, this approach offers a distinct analysis for addressing a variety of specific social concerns, in this case agri-food issues. This framework endeavors to understand and identify crucial structural forces in the social world that are at the basis of social organization and, more generally, social life. In doing so, it seeks to discover the political, cultural and economic factors that are manifestations of social life, with a 
particular interest in the access and distribution of important resources (Balaam and Veseth 2007).

Political economic theories on the environment offer an eco-structural perspective when analyzing social factors in relation to environmental issues, such as the depletion of natural resources. This area of study has made a substantial contribution to the theoretical development within the sub-discipline of environmental sociology (Buttel 2002; Foster 1999; O'Connor 1991; Schnaiberg 1980). In addition, political economic approaches have been at the forefront of empirical investigations in this growing area of sociological inquiry (Grimes and Kentor 2003; Jorgenson 2003; York, Rosa and Dietz 2003). This framework incorporates key macrotheoretical concepts to form an effective approach for analyzing the interactions between social systems and natural systems, providing a critical lens for examining socio-ecological concerns.

The treadmill of production (ToP) theory and world-systems theory (WST) are primary theoretical lenses that have been at the forefront of environmental sociological research (Buttel 1987; Buttel 2002). These theoretical approaches can provide important insight into the processes taking place in the Mediterranean bluefin fishery. ToP theory emphasizes the expansionary nature of the modern political economy in relation to resulting social and environmental outcomes (Schnaiberg 1980; Schnaiberg and Gould 1994). The ToP theory offers an analytical framework that identifies key structures of modern social relations of production and consumption as primary drivers of environmental and social degradation.

The world-systems perspective highlights global political economic processes, examining them in a historical light (Roberts and Grimes 2002). For environmental sociologists, WST has framed analyses to help illuminate the relations between nature and capital in a global sociohistorical context (e.g. Bunker 1984; Moore 2003). This conceptual framework unveils the levers of global power relations, and emphasizes the role of nature and natural resources in the course of world historical political economic systems.

This study seeks to identify and describe the global political economic forces that are driving technological, economic, cultural and environmental change in the Mediterranean bluefin tuna fishery, with a focus on Sicily. It draws from the eco-structural perspective developed in environmental sociology, primarily from a world-systems and treadmill of production frameworks. In this regard, this work will provide a political-economic history of the fishery, situating the socio-ecological transformations that have occurred in their social and historical context. Thus, it is appropriate to proceed with a discussion of the broader background regarding production and consumption of marine products in the modern era.

\section{INDUSTRIALIZATION OF GLOBAL FISH PRODUCTION AND EXPANSION OF CONSUMPTION}

It is crucial to recognize that changes in production and consumption in the agri-food sector have been socially and historically shaped, and have had far reaching social and ecological consequences in the modern world-system (Mintz 1985; Moore 2003). During the twentieth century, and particularly in the post World War II era, food production in most nations that make up the core of the modern world-system began to take on the characteristics of the industrial factory (Goodman 1991). Producing food was transformed into an industrialized process that generated mass commodities for growing global markets (Friedman 1982; Magdoff, Foster and 
Buttel 2000; McMichael 1995). In agriculture, the mass production of food and fiber became possible with the widespread use of synthetic fertilizers and pesticides, the development of new hybrid plant varieties, increasing application of mechanization of production, and the expansion of irrigation, resulting in an era known as the "green revolution."

Mirroring the industrialization of agriculture, the fishing industry adopted capital and hitechnology intensive methods in order to increase capacity and production (Garcia and Newton 1997; Jackson et al. 2001; Pauly 2004). In the modern era, fish production has developed into a highly mechanized, capital and technology intensive system (Bailey 1985). Like agriculture, with the expansion of shipping and transport technologies, marine products increasingly became heavily traded global commodities (Bonnano and Constance 1996; Friedland 2004). This process provides global populations, typically in core nations, with better access to a variety of marine food products at most any time of year. As a result, consumption of marine resources has increased dramatically over the last few decades (UN FAO 2007; World Bank 2006a).

Between 1950 and the late 1980s, the exploitation of global marine resources expanded significantly, from a total of about 20 million tons per year to over 80 million tons per year (UN FAO 2007). Along with the growing affluence of wealthy consumers from the global North, fish production and consumption expanded in a variety of traditional as well as nontraditional markets. Literature on this matter largely points to demographic changes, in particular population growth and consumption trends, during this period as the chief drivers of increasing fish consumption (World Bank 2004).

Nevertheless, it is important to note that during the 1950s and 1960s, and again since the start of the twenty-first century, fish production increased so quickly that it outpaced population growth $^{2}$ (Pauly et al. 2002). Global consumption of fish grew from nine kilograms per capita in 1961 to almost seventeen kilograms per capita in 2003 (UN FAO 2007). Indeed, most of the expansion in fish consumption occurred in nations that have had the lowest levels of population growth in the post World War II era. For example, in core nations, between 1961 and 2003, fish consumption grew faster than population growth (UN FAO 2007; World Bank 2006b). Moreover, social variables such as culture and economic growth have been shown to have a significant influence on fish consumption (York and Gossard 2004).

To fuel the growth in the marine products market, global fishing efforts have intensified. Capital investments were made into improving and increasing capture technology. As a result, larger and more heavily capitalized fishing fleets began to roam the world in search of abundant fish stocks. With advanced location technology, increased size and speed of boats, and better overall capture apparatus, many ocean species have been exploited beyond sustainable limits (Myers and Worm 2003; Pauly et al. 1998; Worm et al. 2006).

\section{EXPANSION OF THE BLUEFIN MARKET}

The Mediterranean bluefin fishery has been heavily exploited in recent years to provide fresh, frozen, and processed tuna for core nations, particularly Japan, followed by Western Europe and the United States (Crescimanno and Di Trapani 2007). The expansion of production and

2 During the twenty-first century this growth in production is mostly due to the mass expansion of aquaculture. 
industrialization of the Mediterranean bluefin fishery is a relatively recent phenomenon. This process was, in large part, set off by the growth of the global sushi and sashimi market that emerged in the late twentieth century. To be sure, as the primary market for bluefin tuna, Japan has been a central driving force behind this expansion (Bregazzi 2006; Crescimanno and Di Trapani 2007).

Marine products have been a longtime staple in traditional Japanese cuisine. As a nation of North Pacific islands, fish provided vital calories and protein for a population with relatively little arable land. Japan's appetite for fish is enormous, a large percentage of which is imported. In 2005, Japan imported over 2.7 million tons of fresh, frozen, processed, and live marine products, more than sixty percent of the 4.36 million tons of domestic production ${ }^{3}$ (UN FAO 2010). That same year, Japan's total seafood imports were valued at more than $\$ 14$ billion (UN FAO 2010).

The Japanese market far exceeds any other market in consumption and imports of bluefin tuna. In 2005, Japan imported fifty-five percent of the entire global imports in Atlantic bluefin tuna $(\mathrm{ABFT})^{4}$. In recent years, Japan, together with Spain, France, United States, and Italy, made up almost ninety-five percent of the global market (Di Trapani 2007). In dollar values, Japan's imports are estimated to reach seventy-five percent of the total value of global imports of bluefin tuna (Crescimanno and Di Trapani 2007). This difference between quantity and value of Japanese imports is an indicator of the high value and "quality" of bluefin tuna that is imported to Japan, as well as the strength of the Japanese market.

With the growth of the Japanese economy in the post World War II era, the demand for bluefin tuna as sashimi and sushi increased dramatically and enormous price escalation followed the swelling demand (Safina 1998; WWF 2002). Specific cuts of bluefin are highly prized and sold in a variety of forms. In Japan, the fatty belly, sold as toro, became a delicacy that began to command the highest prices (Bestor 2004).

At its peak, one portion of high quality sushi/sashimi could easily sell for fifty to one hundred dollars or more in prestigious Japanese restaurants (Bestor 2001). Recently, at Japan's renowned Tsukiji wholesale market, market prices have reached historic highs of $\$ 900$ a kilo (Ellis 2008; Miyake et al. 2003). For example, at Tsukiji's first auction of 2009, a $128 \mathrm{~kg}$ bluefin sold for $\$ 820$ per $\mathrm{kg}$, and a new record was set when a single bluefin was auctioned for over $\$ 200,000$ (Wright 2009). These examples of extraordinarily high market prices are relatively rare occurrences. Nevertheless, they display the soaring global market and transformation of an item that was recently, in market terms, a low-value species. For instance, only a few decades ago, bluefin tuna sold for five to ten cents a pound in the United States market (Gaski 1993; Issenberg 2007).

Although Japanese have consumed sushi for centuries, its earliest forms were salted and fermented fish with rice. Indeed, our common modern notion of sushi and sashimi (raw fish with or without rice) is a rather new culinary concept that transpires with access to modern refrigeration technology. Japanese began consuming sushi rolls at the turn of the twentieth century. Raw sushi, as we commonly know it, only appeared in the post war period, and toro sashimi only in the 1960s (Ellis 2008; Issenberg 2007). Thus, along with changes in technology,

3 Domestic production includes Japanese distant water fishing, not merely vessels in Japanese waters. 4 Atlantic bluefin tuna or Northern bluefin tuna is one of three bluefin tuna species. It inhabits the North Atlantic and Mediterranean region. 
a growing economy, opportunities for investments and profits, and expanding global trade came changes in culinary practices and consumer tastes. Traditional cuts of preserved or fermented tuna gave way to new patterns in production, distribution and consumption.

\section{Bluefin Tuna: From Cat Food to High Class Cuisine}

Before the recent bluefin tuna market boom, Atlantic bluefin tuna was a species that was generally of little interest to most fishing operations. ABFT had a relatively low market value and was minimally exploited, particularly in comparison to other tuna species such as albacore or skipjack. In the West Atlantic, bluefin tuna were hunted mostly for sport, since their large size, tremendous strength and great speed offered a considerable challenge to recreational fishers (Whynott 1995). Many commercial fishing operations regarded them as a nuisance, as bluefin tuna are voracious eaters and would frequently consume commercially viable target species (Safina 1998).

In Sicily, bluefin tuna was a traditional and seasonal fare that made an important contribution to the food resources in coastal communities. It was often preserved under salt or oil for later consumption. Several bluefin dishes were deemed "cucina povera," or food of the poor.

In Western markets, bluefin tuna was typically destined for pet food plants. Even in Japan, when bluefin was consumed regularly, fatty parts of the bluefin tuna were considered undesirable or even inedible. Indeed, the fatty belly, now the highly praised toro, was frequently tossed to cats (Ellis 2008; Issenberg 2007). Generally, the red flesh of species like tuna was not highly regarded as white flesh species. In the post war period, particularly by the 1970s and 1980 s, with a newfound appreciation for its high fat content, toro emerged as a luxury food item in Japan. Bluefin tuna, called maguro, was transformed from cat food to fine Japanese cuisine. In a short time, its value on the Japanese market jumped an astonishing 10,000 percent, with similar spikes throughout the world (Bestor 2001; Issenberg 2007).

In Japan, maguro toro became the superstar of sushi/sashimi. While other species are utilized in the production and consumption of sushi and sashimi, bluefin tuna is commonly regarded as the highest quality and most desirable species for this type of consumption (Bestor 2001). With the growing prosperity of Japanese consumers, high-end restaurants and elite sushi bars in Japan began offering this newly esteemed dish, which is regularly consumed by business elites. Surely, for the Japanese upper class, there was no substitute for maguro toro as a status symbol. While the bluefin tuna market has gone through periods of highs and lows in recent years, Japanese imports have remained relatively stable $^{5}$ (Table 1). Within a short time, the growing trend in Japan was transported to other wealthy nations, and in the 1990s sushi was the latest food fad in core nations in Western Europe as well as the United States (Bestor 2001). Following this period, bluefin tuna became the most demanded and expensive tuna species on the world market (Ottolenghi 2008).

5 During this period, Japanese imports saw marked increase in frozen fillet. This change to frozen fillet apparently results from a simple categorical modification, which has increased likely due to the fact that a large amount of frozen fillet can be imported without properly identifying it as ABFT. This, along with many other efforts, has often been done to circumvent regulations imposed by ICCAT. 
Table 1: Recorded Japanese Imports of ABFT in tons and values ${ }^{6}$ (NOAA 2010) ${ }^{7}$.

\begin{tabular}{|c|cccccc|}
\hline \multirow{2}{*}{ Fresh } & 2004 & 2005 & 2006 & 2007 & $\mathbf{2 0 0 8}$ & 2009 \\
\cline { 2 - 7 } Frozen & $\mathbf{9 , 9 6 6}$ & $\mathbf{9 , 8 8 2}$ & 7395 & 5114 & $\mathbf{4 , 3 5 1}$ & 5,834 \\
Frozen Fillet & $\mathbf{6 , 6 2 4}$ & $\mathbf{4 , 2 2 0}$ & 5355 & 6283 & $\mathbf{4 , 1 7 8}$ & 3,991 \\
\hline Total (Tons) & $\mathbf{8 , 8 4 1}$ & $\mathbf{1 0 , 4 6 6}$ & 15542 & 13451 & $\mathbf{1 3 , 6 2 7}$ & $\mathbf{1 3 , 1 9 8}$ \\
Millions of Yen & $\mathbf{5 3 , 4 3 1}$ & $\mathbf{2 4 , 5 6 8}$ & $\mathbf{2 8 , 2 9 2}$ & $\mathbf{2 4 , 8 4 8}$ & $\mathbf{2 2 , 1 5 6}$ & $\mathbf{2 3 , 0 2 3}$ \\
Millions of Dollars & $\mathbf{4 9 2 . 3 6}$ & 52,527 & $\mathbf{6 4 6 6 4}$ & $\mathbf{6 3 2 6 7}$ & $\mathbf{6 8 , 1 7 2}$ & $\mathbf{5 7 , 2 2 1}$ \\
\end{tabular}

NOAA's Southwest Regional Office reports that between the years 2004 through 2009, Japan imported an average of about 22,500 tons of ABFT each year (NOAA 2010). These imports had a six-year average value of $\$ 531$ million per year. However, Japanese imports are higher than the NOAA data suggests, as most official estimates do not consider illegal, unreported and unregulated (IUU) captures. (Bregazzi 2005; Volpe 2005; WWF 2008). Thus, the global market for bluefin tuna is much larger than most official sources report. Once on the consumer market, the total value of bluefin sales is likely in the billions of dollars ${ }^{8}$.

Bluefin captured in the Mediterranean Sea account for the largest share of the total ABFT exports. As catches of Pacific bluefin (thunnus orientalis) and Southern bluefin (thunnus maccoyii) dropped, particularly in the 1980s, ABFT (thunnus thynnus) became the central bluefin target species. The Mediterranean is one of the few remaining areas where ABFT remain relatively abundant. Other ABFT fishing zones, especially in the western Atlantic, have seen significant reductions in captures in the last few decades (ICCAT 2007a; Safina and Klinger 2008; Safina 2003).

\section{Transformations in the Global Bluefin Market}

The expansionary nature of the capitalist treadmill of production (Schnaiberg and Gould 1994) and the technological operations that emerged within the natural and social context of the modern world-system (Bunker and Ciccantell 2005) played a central role in transforming and shaping the modern global bluefin market. With such a high price on its head, fishing effort for bluefin tuna expanded quickly throughout the world. The growing value of bluefin tuna on the global market was related to a number of important social phenomena that are crucial for understanding the expansion of ABFT captures in the Mediterranean, and the impacts on ABFT populations and the communities that were traditionally tied to the species.

\footnotetext{
${ }^{6}$ Values were estimated using the annual average exchange rate for the year considered.

${ }^{7}$ While data from NOAA dates back to 1996, previous to 2004 the category "frozen fillet" was not included in their data. Therefore, to remain consistent, those data were excluded from this table. 8 Unfortunately, it is impossible to estimate the actual values of bluefin tuna imports due to high levels of IUU captures. Recent estimates state that the captures of ABFT may be double the reported captures and exports/imports (ICCAT 2007c).
} 
GLOBAL SUSHI 410

Table 2: Mediterranean Bluefin Tuna Exports. Average Estimated Values ${ }^{9}$ and Quantity in Tons with Nation of Origin (2004-2005) (Bregazzi 2006).

\begin{tabular}{|c|c|c|}
\hline & & \\
Export Nation & Value in Dollars & Tons \\
\hline Spain & $62,416,691$ & 9,390 \\
Turkey & $40,204,093$ & 3,490 \\
Malta & $35,748,830$ & 3,113 \\
Croatia & $32,643,270$ & 3,166 \\
France & $32,011,181$ & 7,078 \\
Italy & $30,863,204$ & 5,969 \\
Tunisia & $16,108,134$ & 1,437 \\
Morocco & $7,081,593$ & 736 \\
Cyprus & $5,632,880$ & 1,025 \\
Libya & $3,755,849$ & 559 \\
Greece & 445,719 & 1,981 \\
\hline Total & $266,911,441$ & 37,943 \\
\hline
\end{tabular}

First, because of the high price of bluefin tuna, it became economically viable to transport freshly caught individual bluefin tuna via airplanes to high value markets. Japan Airlines considered fish an ideal food commodity for air travel, and was the first operation to attempt the air transport of bluefin tuna (Issenberg 2007). Using jet aircrafts, a bluefin tuna caught off the coast of Maine or Sicily could be delivered to Japanese consumers within twenty-four hours of its capture. For example, in 1991, the United States exported almost \$16 million in bluefin tuna to Japan by way of air (Gaski 1993). Even though the local Pacific bluefin tuna has been the preferred species in Japan, as a result of high-speed transport, ABFT from distant waters also became a luxury food item for elite Japanese consumers.

Second, new technology in food storage, including cooling and freezing technology, allowed for the conservation of bluefin tuna in a way that maintained much of its perceived quality. Methods were developed that preserved freshness by maintaining constant proper temperatures without freezing. In addition, superior freezing and thawing technologies were advanced that allowed the fast freezing to very low temperatures of negative forty-five degrees Celsius (UN FAO 2004). Other emerging technologies in production also became viable, namely "tuna farming" or "tuna ranching," which created a novel way to add value to bluefin tuna and produce sushi quality tuna. While frozen bluefin and some farmed tuna are not regarded as

\footnotetext{
${ }^{9}$ These are estimates based on analysis by Advance Tuna Ranching Technologies (ATRT), for the years 2004 and 2005. ATRT has compiled data on bluefin tuna in the Mediterranean using a wide variety of official and industry sources. Due to the high level of IUU activities in the fishery, precise data is unavailable. These estimates are likely some of the best that are available. Values were estimated using the annual average exchange rate for the year considered.
} 
highly for the quality characteristics that are determined by expert sushi graders, these methods certainly opened up a medium-quality sushi market.

Graph 1: Total Recorded Global Captures of Bluefin Tuna by Species (UN FAO 2010).

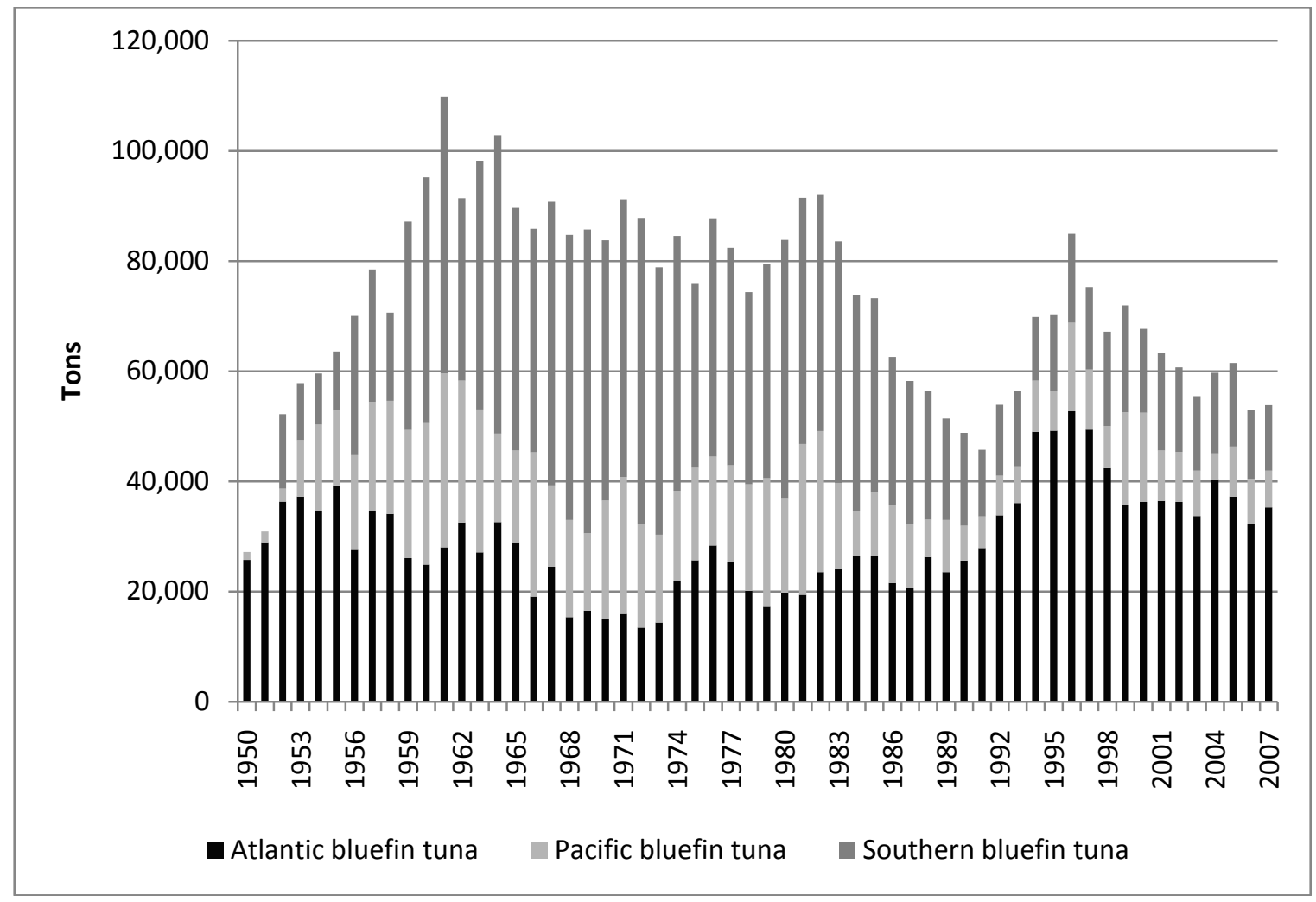

Third, the expansion of the middle-range market spurred a boom in consumption of bluefin tuna (Tudela and García 2004). The burgeoning Japanese middle class could now consume this luxury food item that was previously reserved mostly for the upper class and business elites. Bluefin tuna began to show up on the menus of middle range sushi bars and later "fast food" style conveyer belt sushi bars (Bestor 2001). Together, these processes contributed to the expansion of a global market for ABFT. Along with Tokyo, restaurants from Los Angeles to London were offering ABFT sushi and sashimi on their menus and producers were striving to push into new and growing Asian markets. By the 1990s, bluefin tuna became a global food commodity for those with a taste for luxury.

\section{INDUSTRIALIZATION OF THE MEDITERRANEAN SEA}

This lucrative and growing global market for bluefin tuna necessitated mass production and economies of scale. Industrialized fishing, already active in many fisheries by the late twentieth 
century, became the modus operandi in bluefin tuna fisheries. The Mediterranean bluefin fishery, one the oldest and most productive bluefin fisheries in the world, became the target of industrial fishing operations in an attempt to capture this high-value commodity and exploit a profitable and expanding market.

Graph 2: Total Recorded Captures of ABFT in the Atlantic Ocean and the Mediterranean Region $^{10}$ (ICCAT 2007c).

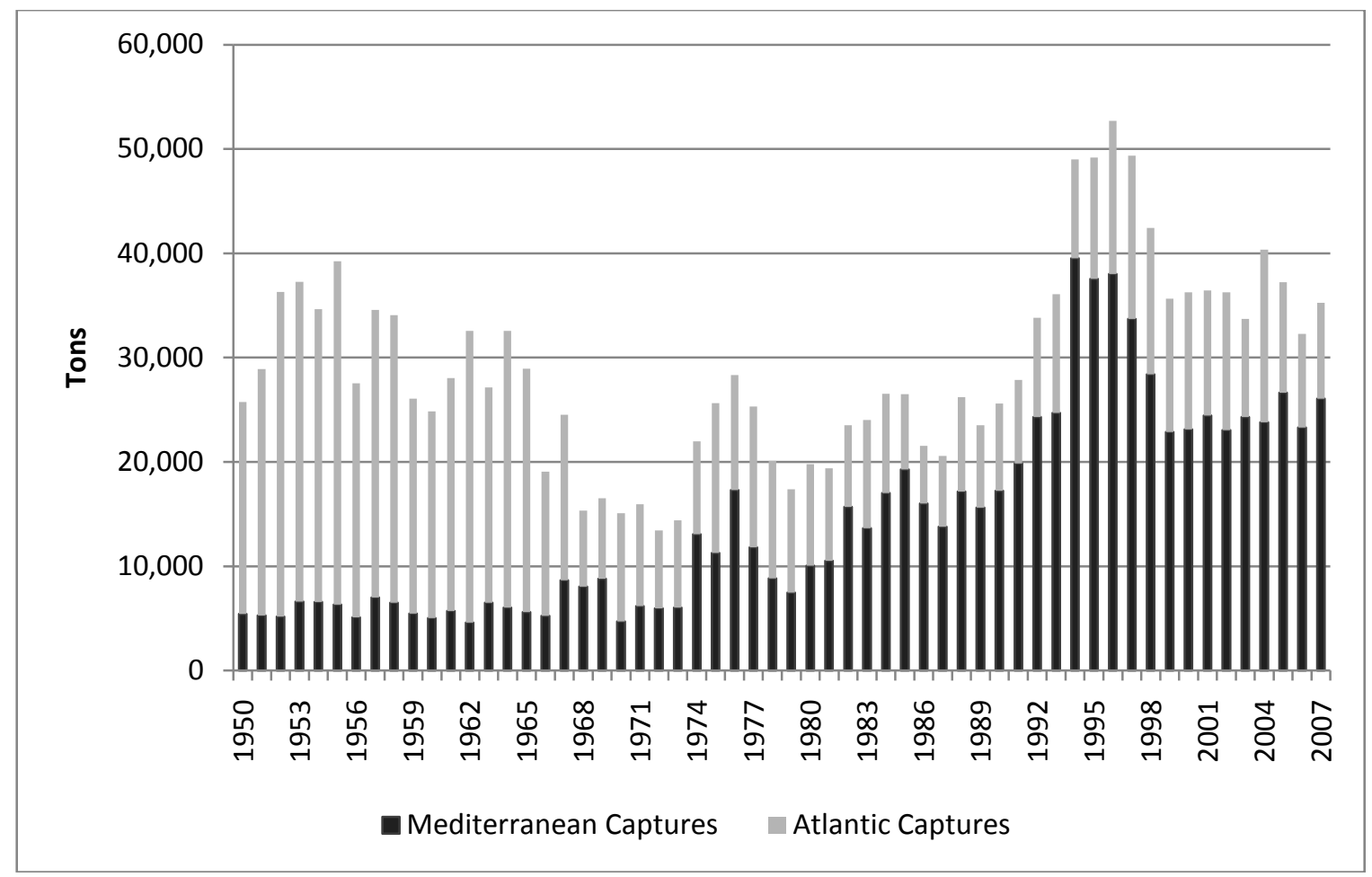

Two of the most common methods of fishing used in modern bluefin tuna fisheries are long-lines and purse-seines. Long-lines are fishing lines baited with hooks and can range from a few miles up to eighty miles in length. These lines can contain thousands of baited hooks (Ellis 2003). Japanese long-lines began steadily fishing in the Mediterranean in 1972 and quickly found an abundant source of bluefin tuna. In that year, long-liners from Japan captured about 70 tons of bluefin in Mediterranean waters. Just two years later, Japanese captures increased more than tenfold (Mather, Mason and Jones 1995). Japanese long-line vessels were seasonally banned

\footnotetext{
${ }^{10}$ As mentioned above, IUU captures have been significant in the Mediterranean region. As a result, since the late 1990s ICCAT has reduced capture quotas for member nations and their fishing fleets. The stark drop in captures visible in the late 1990s and 2000s is related to the reduction in quotas. However, IUU captures are not included in these data and likely increase real captures significantly. Mediterranean captures also include the Black Sea.
} 
from the Mediterranean by 1975 in an agreement between Japan and the International Commission for the Conservation of Atlantic Tuna (ICCAT) (Miyabe 2003). However, this method of capture is still in use. In 2000, over one billion hooks were set throughout the ABFT fishery (Duncan and Woolford 2006). Long-lines do not distinguish between old and young fish, or even specific species. As a result, they commonly hook non-target species such as sea turtles, marine mammals, and a variety of sea birds (Safina 1998).

Purse-seining involves large nets, some of which are large enough to encircle a football stadium (UN FAO 2008). These nets are deployed into the oceans vertically, in a cylinder like fashion, with a float line at the top and a lead-line at the bottom, which encircle schools of fish. Once the tuna are inside, the bottom of the seine is drawn closed using the purse line, trapping sea-life inside the large area surrounded by nets. Auxiliary vessels such as skiffs or speedboats, and sometimes helicopters, are also used in this practice (UN FAO 2008).

Purse-seine fishing for ABFT in the Mediterranean usually takes place during the spawning period. The earliest use of purse-seines in the North Atlantic fishery was in Norway during the 1940s. By the 1950s, purse-seines were capturing over 10,000 tons of ABFT in this fishery, and by 1972 this North Atlantic fishery collapsed to a capture of only one hundred tons (Mather et al. 1995). In the Mediterranean, purse-seining became a regular method of capture by the 1970s, expanding rapidly thereafter. In recent times they have been used to capture live "seed" stock for bluefin ranches (Ottolenghi et al. 2004). Under these circumstances, they are not hauled aboard the vessel, but kept alive awaiting transfer.

\section{Graph 3: Recorded Sicilian Trap and Mediterranean Purse-Seine ABFT Captures (Bregazzi 2005; ICCAT 2007c).}

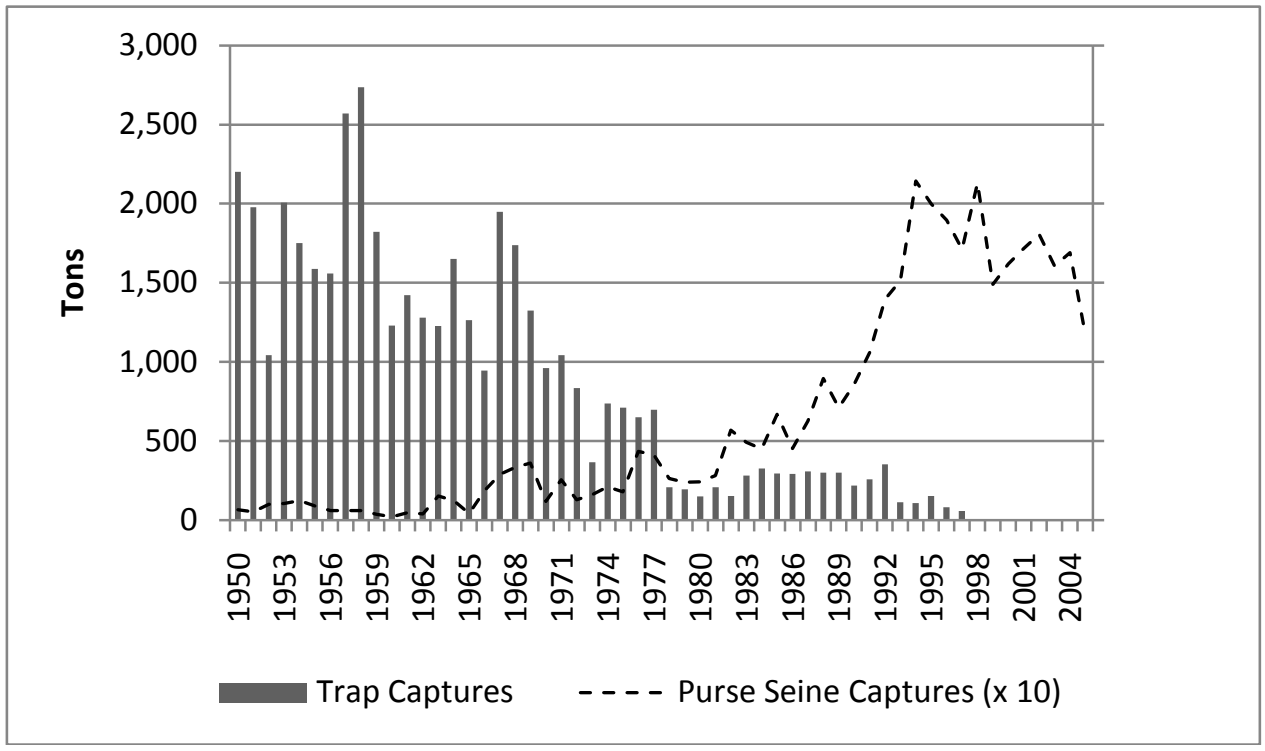

By the 1980s, larger nets, more powerful deck machinery, and generally bigger vessels to transport and store larger catches were implemented, (Safina 1998). Along with these large-scale 
capital-intensive fleets, high technology has been incorporated into fishing for bluefin. New technologies have been used to pinpoint and capture stocks moving throughout the ocean. These include innovations such as Doppler radar, spotter planes, bird locating radar, omni-scan sonar, fish aggregating devices, satellite-derived sea surface temperature information, and radio buoys (Safina 1998; UN FAO 2008). As a result of the growth in capital and technology investments, the capacity of the Mediterranean purse-seine fleet has expanded tremendously, far beyond the regulated capture quota for the region (ATRT 2008).

In effort to create greater economic efficiency in live capture for ranching, purse-seine fleets continually increased investment into a number of areas of the fishing process, including faster engines, better detection and communication technology, increasing the number of skiffs, employing faster auxiliary vessels, implementing new technology to lift and move skiffs, as well as using larger and faster sinking nets (Bregazzi 2005; WWF 2006). This was done in order to locate, reach, and secure bluefin before competing purse-seines could reach the migrating school, and reduced the potential for speedy bluefin to escape capture.

The "modernization" of the purse-seine fleet has resulted in increasing investment and boats fitted with the latest technology are valued at almost six million dollars (Ottolenghi 2008). It is important to note that a large part of the "modernization" of the European purse-seine fleet was subsidized by public funds (Tudela and García 2004). Recent estimates suggest that between 2000 and 2008 the European Union provided the fishery with almost 35 million Euros in public subsidies, the vast majority of which was used to increase fishing effort (Pope 2009). The Mediterranean purse-seine (PS) fleet is characterized by

"high initial and revolving capital investment, stringent amortisation and financial costs, as well as ever-growing operational overheads (fuel, fishing licenses, tuna spotting airplanes, labour, maintenance and repairs, insurances, etc...The entire Mediterranean BFT PS is therefore faced with a minimal yearly BFT catch, necessary to at least cover for expenses and amortisation of such ships....every single one of these fishing units is operated, either as an autonomous business profit-centre or as forming part of a fishing fleet operated [by] the same business parameters" (ATRT 2008:87).

Therefore, Mediterranean purse-seine operations are under heavy economic pressure to locate and capture ABFT to meet higher operating costs and increase profits, which can be used to stay ahead of the competition through more investments in technology and capacity, feeding the treadmill of tuna production (Schnaiberg and Gould 1994). Further, as Schnaiberg (1980) made clear, industry and the state have come together in a common interest to power the treadmill of production by investing in the fishery, and limiting regulations and capture quotas.

Consequently, traditional fishing methods in the Mediterranean were replaced by capital and technology intensive methods. The Sicilian trap fishery, la tonnara, experienced a collapse in captures (Graph 3). The traditional bluefin tuna trap fishery has a long history of supplying food resources for the region in a sustainable manner (D’Amico 1816; Sará 1998). While early in the industrial expansion of the fishery Sicilian traps were a source for the global bluefin market, a fleet of industrial vessels that were adept at capturing bluefin tuna before they reached traps quickly replaced them. Also, the modern industrial fleet can capture young bluefin of prespawning age. ABFT are believed to reach spawning age relatively late, after five years of age 
(Schaeffer 2001). Over time, capturing pre-spawning age fish can have devastating impacts on stocks (Safina 2001). In addition, increased pollution due to industrial activities has impacted the traditional trap fishery (Addis et al. 2007).

Due to the competitive nature of production, market dynamics, and technological "modernization" that began in the post-war era, expanding fishing operations were chasing after finite stocks of ABFT. Competition became fierce and stocks began to show signs of distress. In Sicily, as well as other parts of the Mediterranean, traditional trap fisheries collapsed. The historical record reveals that the island consistently contained around twenty trap fisheries for at least two centuries, and often many more (D'Amico 1816; La Mantia 1901; Villabianca [1764] 1986). Today the traditional tonnara fishery in Sicily is defunct. In some locations where trap fisheries were located, a new technology replaced the traditional method: bluefin tuna ranching.

\section{Sushi Farming: Bluefin Tuna Ranching}

In the late twentieth century, global fish consumption expanded with the help of aquaculture production. As global marine captures could not keep pace with the expanding markets, typically in core nations, industrial aquaculture emerged as the strategic method to augment production (Bailey, Jentoft, and Sinclair 1996; UN FAO 2007). Inspired by the growing market in aquaculture products and its industrialized production methods, bluefin tuna "farming" was adopted as a way to further expand and control production, and increase surplus value.

Tuna farming or ranching, sometimes referred to as "capture-based aquaculture" (Ottolenghi et al. 2004), is a form of intensive tuna production that in many ways parallels feedlots used for livestock production on land. Bluefin are captured and placed in feeding cages to rapidly increase weight, and specifically their fat content, until they are ready for slaughter. Unlike conventional industrial aquaculture systems, such as those used in salmon, sea bass, tilapia, and others, there has been little success rearing bluefin tuna in controlled environments ${ }^{11}$. The "domestication" of bluefin tuna for commercial mass production has been a process that has thus far eluded scientists and industry (Sawada et al. 2005).

Given that closing the bluefin tuna life cycle in captivity for commercial production has been difficult to achieve, purse-seines capture wild "seed" stocks that are transported to fattening facilities, many of which are in the Mediterranean. In 2008, there were almost seventy registered bluefin tuna ranching facilities throughout the Mediterranean in eleven countries, with a potential capacity of over 63,000 tons (ICCAT 2008).

Captured bluefin are transferred from purse-seine nets to sea cages, and transported by tugboat to the ranching facility. Moving at the careful pace of about one to one-and-a-half knots to avoid harming the valuable cargo, transport can take many days, weeks or, even more than a month. Some firms are vertically integrated, which allows for easier coordination of this mammoth undertaking (Bregazzi 2005).

In the wild, bluefin tuna are opportunistic feeders, preying on an array of small and large species. However, in captivity, they are fed a diet of frozen fish selected for the high oil or fat content to produce bluefin that meet the quality demands of the relatively new sushi and sashimi markets. The feed is usually made up of some combination of herring, sardines, mackerels,

11 There have been some recent breakthroughs in domesticating Southern bluefin (thunnus maccoyii) and Pacific bluefin (thunnus orientalis) and the completion of the life cycle (Ellis 2008; Sawada 2005). 
anchovies, and squid. Feed fish are occasionally procured locally, but the majority has been imported from outside the region, including from the Americas (Ottolenghi 2008). Throughout the process, ranches attempt to increase the quantity of feed to levels that approach seven to ten percent of the bluefin tuna's weight, with an average consumption of five to six percent of body weight per day. Therefore, a bluefin tuna ranch with a capacity of 1,000 tons can consume an average of fifty to sixty tons of feed fish per day. ABFT are kept in ranches anywhere from four months and, in some locations, up to two years.

Graph 4: Recorded Tuna Ranch Production and Capacity (ICCAT 2007c; Miyake et al. 2003; UN FAO 2010)

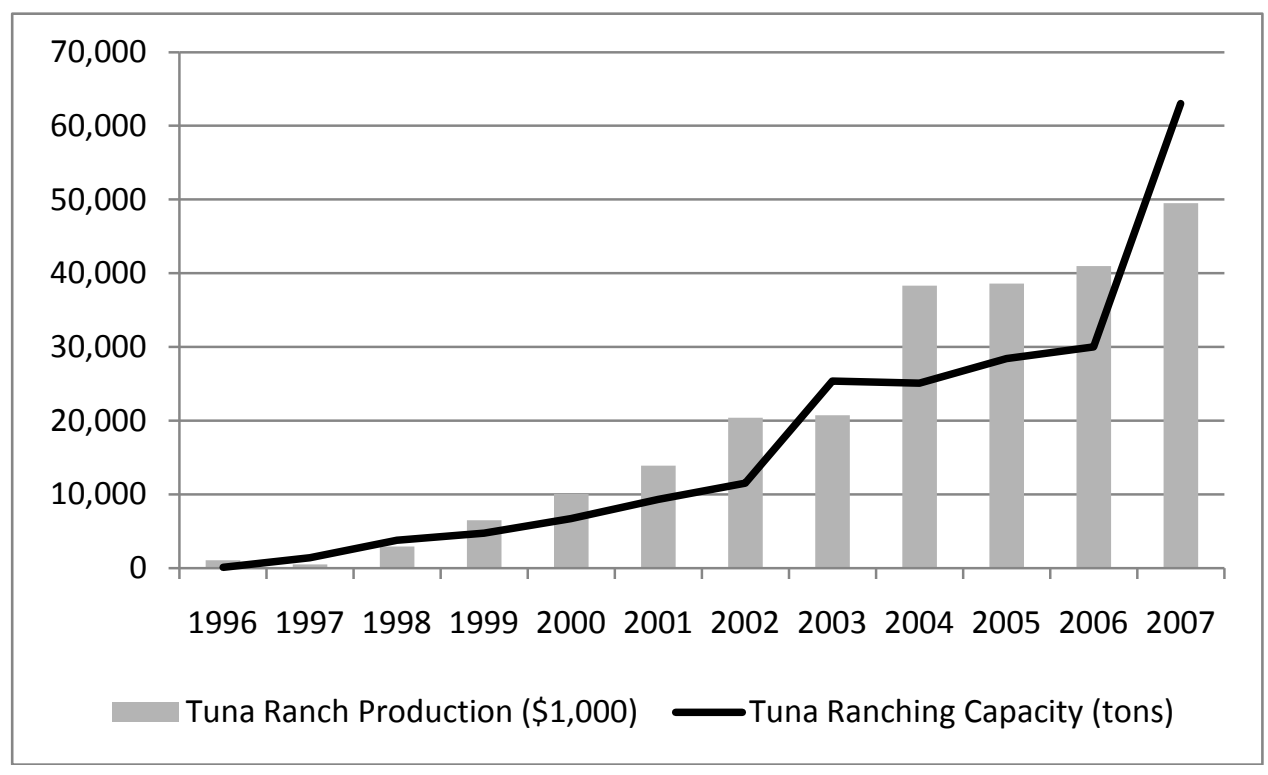

The global supply of ranched bluefin tuna reached over 20,000 tons by the year 2000, about half of which came from the Mediterranean (Miyake et al. 2003). In the following five years tuna ranching production in the Mediterranean tripled. This growth continued and capacity in the Mediterranean doubled again after 2005 (ICCAT 2008). Consequently, up to eighty percent of Mediterranean exports of bluefin tuna to Japan originated from tuna ranches (Ottolenghi et al. 2004; Tudela and García 2004).

Tuna ranches have become the main supplier of ABFT for the global market. As Mediterranean bluefin became a major supplier for Japan, the markets were linked. Ranching methods were adopted primarily to maintain the "quality" and supply for the sushi and sashimi market. Thus, over a few decades, the Mediterranean bluefin tuna fishery has been transformed from a long-standing sustainable trap fishery that supplied mostly regional populations, into a globalized industrial fishery, guided by the dictates of transnational capital, supplying fattened bluefin for global elites. 


\section{Graph 5: Recorded Values of Mediterranean Bluefin Tuna Exports and Japanese Imports (UN FAO 2010)}

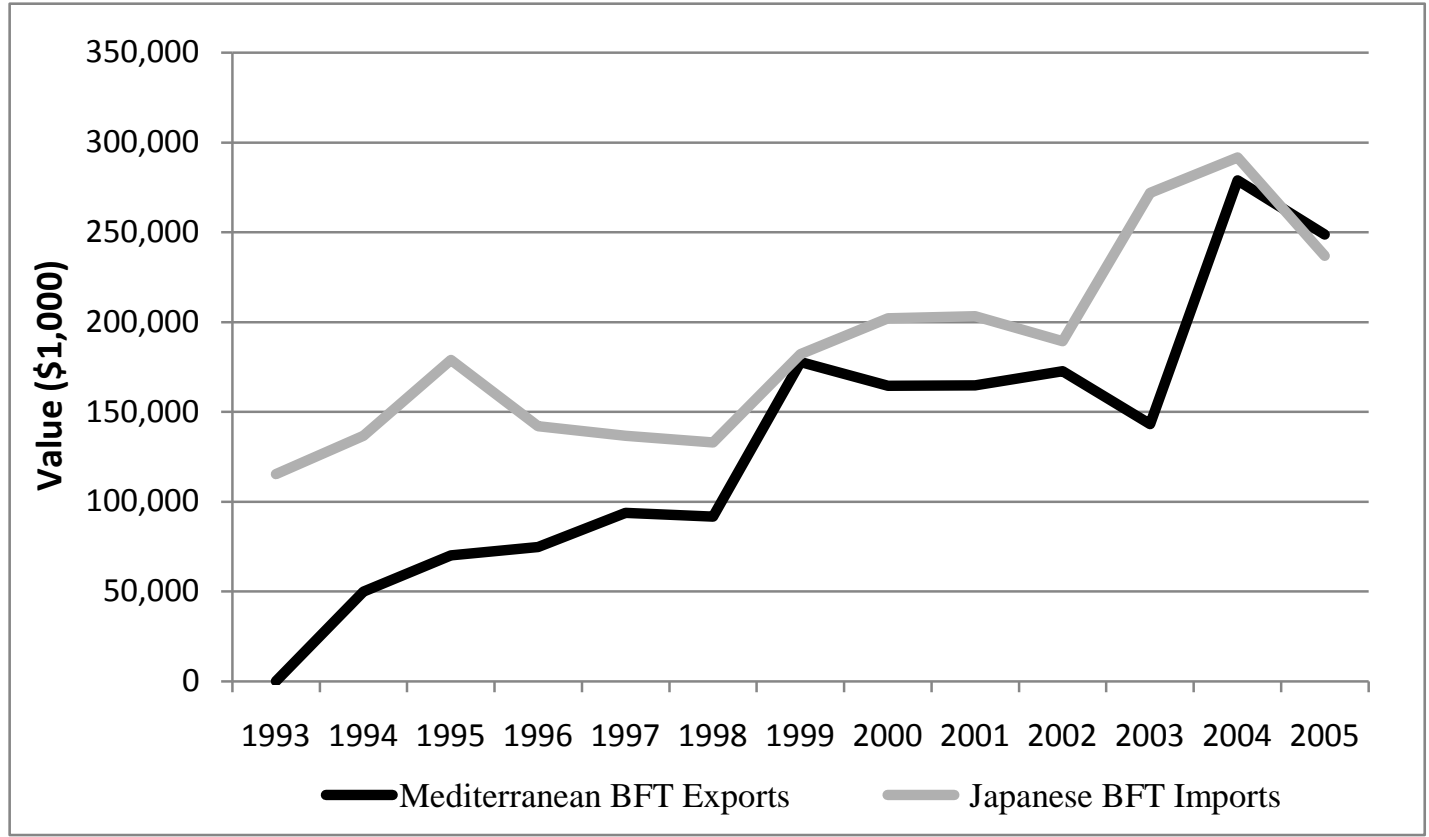

\section{Mediterranean Bluefin Tuna Ranches and Transnational Capital}

Tuna ranching firms have been vertically integrated joint ventures dominated by Japanese, Spanish, Korean, and French trans-national corporations (TNC) (ATRT 2006). The leading players in the Mediterranean have been the Japanese firms Mitsui and Company. Ltd. and Mitsubishi Corporation, as well as the Spanish firm Ricardo Fuentes e Hijos S.A. The Japanese firms are among the largest TNCs and have operations in a number of sectors. The Spanish firm (Fuentes Group) is the largest producer, processor and distributor of tuna products in the Mediterranean (Bregazzi 2005; Fuentes Group 2007).

The size and scope of the major firms are enormous. For example, in the fiscal year 2006-2007, Mitsubishi earned nearly $\$ 10$ billion in gross profits (Mitsubishi Corporation 2007b). This TNC has operations in agricultural products, food and beverages, textiles, construction materials, metals, machinery, energy, chemicals (petrochemicals, fertilizers, plastics), software, telecommunications, and consumer electronics, among others (Mitsubishi Corporation 2007a). Mitsui's gross profits in the same period were more than $\$ 7.5$ billion, with production and distribution in food and retail, mining, petrochemicals, shipbuilding, construction, aerospace engineering, chemicals, and iron and steel production to name a few (Mitsui and Company $2007)^{12}$.

12 Values of profits were determined using an exchange rate of 118 yen equal to one U.S. dollar. This exchange rate is an annual average based on the monthly rate for the year 2007. The original values are 
The Japanese TNCs have been the major financiers of bluefin tuna ranching operations in the Mediterranean. Commonly, Japanese firms worked together with others with expertise in the logistics of tuna ranching, such as the Spanish firm Fuentes Group. Fuentes was founded in the 1960s as a seafood purchaser, processor and distributor. The firm has specialized in fresh and frozen bluefin tuna production and distribution, but also produces and distributes other tuna (such as skipjack, yellow fin and big eye) as well as other species such as sea bass, swordfish, and sardines. However, the firm has emphasized that bluefin tuna is their "star" product (Fuentes Group 2007). The Group is made up of over 25 companies working within the seafood industry, including bluefin tuna "aquaculture" (ranching), sea bass and sea bream aquaculture, salting and processing, extractive fishing, storage and freezing, sales and distribution and transport (Fuentes Group 2007). Their vertically integrated structure allows them to play a role in a number of tuna ranching operations throughout the Mediterranean Sea.

In the 1980s, the Fuentes Group began to collaborate with large Japanese multinationals including Mitsui, Mitsubishi, and the next biggest Japanese firm in the sector, Maruha, and initiated its bluefin export business to Japan. In 1996, they established joint venture operations with these major corporations to, according to their web site, "increase efficiency of bluefin production and export" (Fuentes Group 2007). That is, they began to develop tuna ranches in the Mediterranean with the help of Japanese capital. Fuentes' bluefin tuna ranching operations are located throughout the Mediterranean, and recent ventures include ranches in Libyan and Tunisian waters (Bregazzi 2005).

While this method of production has been lucrative for some and allowed for the expansion of production in the Mediterranean, it has not come without consequence. The notion of "efficiency" that is referenced above ignores ecological laws. Economic outcomes, tied to growing production and improving profit margins, are regarded as a central measure of efficiency. However, the environmental and social consequences must be understood.

\section{BLUEFIN RANCHING: ENVIRONMENTAL CONCERNS AND SOCIAL CONSEQUENCES}

Tuna farming/ranching has come under a great deal of scrutiny from environmentalists and environmental organizations, particularly in Europe. This has mainly been due to the increasing fishing pressure on ABFT since the emergence of tuna ranches in the Mediterranean. It has been argued that this method of production is directly responsible for the increases in capacity of purse-seines in the region (ATRT 2008; ICCAT 2007a).

There is little doubt that ABFT are under mounting pressure and that this has become a serious concern for the future viability of the stocks. In recent decades, the Mediterranean ABFT populations have been seriously depleted and the IUCN has declared that bluefin stocks are endangered (Safina 1996) ${ }^{13}$. As is clear from data presented by ICCAT (2007c) as well as other

$¥ 1,148.1$ billion for Mitsubishi, and ¥903 billion for Mitsui (Mitsubishi Corporation 2007b; Mitsui and Company 2007).

13 The IUCN uses a diverse set of criteria to determine whether species face risks of extinction or vulnerability and categorizes threatened species accordingly. A detailed explanation of the IUCN Red List 
research groups (ATRT 2006; 2008), purse-seine captures, most of which have been destined for ranching facilities, have been on the rise, and fishing capacity has been outpacing captures ${ }^{14}$.

Tuna ranching has also been associated with a number of other environmental concerns including the increasing pressure on feed species in other fisheries, inefficient use of energy resources, and the accumulation and concentration of unconsumed feed and waste resulting from intensive feeding operations. In addition, bluefin tuna has likely the highest food conversion ratio (FCR) of any farmed fish. Its FCR of approximately 20:1 or 30:1 far exceeds most carnivorous species like, for example, salmon (Tudela and García 2004). That is, increasing the weight of a bluefin tuna by one pound requires about twenty to thirty pounds of feed fish.

Therefore, ranching ABFT does not increase food production. The result of this process of modern capitalist industrial food production is a net energy loss. Tens of thousand of tons of edible marine species are lost at each ranching facility due to the ecological inefficiency of this method of production; not to mention the massive amounts of fossil fuels that are required to run a ranching operation. In addition, health organizations are recommending that individuals, particularly pregnant women and children, limit their intake of tuna due to high levels of mercury (Burros 2008). It is not known whether tuna ranches intensify this problem. However, if the results from industrial aquaculture of other species, such as salmon, are any clue, the indications do not portend well (Naylor et al. 1998; 2000).

Socially, the transformation of this fishery has had tremendous impacts on small-and medium-scale fishing and the communities tied to them. In Western Sicily, traditional trap fishing played a central role in social life in the coastal communities of this region. The collapse of the traditional fishery has had serious implications for the economy and culture of the region. Artisanal bluefin fishing, which had been a reliable source of employment and food for generations of families, has come to an end in recent decades.

In many of the coastal communities in the region (e.g. Favignana, Castellammare del Golfo, Bonagia), the tonnara was a fundamental aspect of cultural heritage, community identity and economic life (D'Amico 1816; Villabianca [1764] 1986; Lentini 1995). Not only did the tonnara provide a source of jobs for mariners, but it was associated with a host of land based activities that had great economic importance. Building and maintaining boats, nets and other gear was a significant economic activity in this region (Consolo 1986). With the loss of the traditional sector, familial and cultural ties have been broken. Moreover, while production still takes place in the region, most of the wealth is extracted from the local populations to the largest TNCs in the global fishing sector.

Fieldwork in the region, including in-depth interviews, suggests that the tonnara system of fishing was more than just seasonal employment; it was a way of life. Each trap fishery supplied an important source of income (and food) for close to a hundred families in each tonnara

of Threatened Species and the criteria used for determining the conservation status of plant and animal species is available at http://www.iucnredlist.org/about/red-list-overview.

14 There has been a great deal of controversy surrounding the state of the bluefin tuna stocks in the Atlantic and Mediterranean. While this discussion is beyond the scope of this paper, it is important to note that a serious concern in the fishery is high degree of illegal, unreported, and unregulated (IUU) captures. The extent of IUU captures is unknown, but it speculated to result in a high proportion of all captures.

Consequently, debates on the state of the fishery have ensued between industry and environmental organizations, as the available data is considered to be unreliable. Nevertheless, the available data and observation suggest considerable decreases in stock biomass. 
community. Culturally, this activity was celebrated through festivities and festivals and, over time, its loss has had significant impacts on community life. Participants expressed a feeling of loss and regret that still hangs over many of these communities, as a central aspect of social life vanished. Fishing, and the culture surrounding it, fundamentally defined these communities, and the tonnara was clearly the most celebrated of these activities.

Beyond the tonnara, there have been other drastic changes in Sicilian communities in the last half-century. There have been efforts to increase industrialization and service industries, typically tourism, in Sicily. These efforts have affected small fishing and agriculture communities in numerous ways, including reshaping employment opportunities with the transition into a new economy focused on the service sector.

Today, many Sicilian communities suffer from high unemployment, particularly among the younger members. It is difficult to obtain accurate statistics on the exact unemployment rate for small fishing towns, but in the province of Trapani, in Northwest Sicily, the rate of unemployment in $2003^{15}$ was thirteen percent, the lowest level in five years. For residents below the age of twenty-four it was above thirty-six percent. This is compared to an unemployment rate in Italy during the same year of almost eight and one-half percent (ISTAT 2010).

Furthermore, Sicily has commonly had the highest unemployment rate of any Italian region. In 2003, the unemployment rate throughout Sicily was over twenty percent (ISTAT 2010). Much in the form of treadmill rhetoric, tuna ranching operations promised jobs for the local economy. For example, in Castellammare del Golfo, a historic Sicilian fishing town, the system was pitched to locals as an opportunity to increase economic activity and jobs in an economically depressed region. However, at least in this community, the results did not meet expectations, and tuna ranches provided few jobs for locals, and sometimes brought in foreign workers.

Many fishing communities in Sicily have undergone vast demographic changes. During the twentieth century Sicily experienced periods of mass emigration to Northern Italy, Europe, particularly Germany, and the United States (Ginsborg 2003). In many small Sicilian fishing communities, it is very common to find individuals with family and friends who have emigrated. Favignana is useful to examine in that it is an island community in Northwest Sicily that had one of the Mediterranean's largest tonnara. According the Comune di Favignana (2008), in 1961 the island had a population of 6,626 residents. By 2001, 4,137 residents remained in Favignana, an almost thirty-eight percent reduction. Thus, during the period when Favignana's traditional fishery was transformed from an active fertile tonnara to a shadow tourist attraction, and finally to its demise, there was a clear demographic shift.

Interestingly enough, Favignana has recently faced a housing boom as wealthy Europeans purchased or constructed vacation homes on the island. Vacation homes have grown "come le funghi" (like mushrooms). This has had the effect of increasing home values and making it difficult for potential first time homebuyers. Commonly, individuals who previously made their living from the sea have shifted to the tourist industry, found work elsewhere with the hopes of returning, or left the island altogether.

As stated above, surely these unemployment statistics and emigration rates are caused by much more than the transformation in the ecology and economy of the bluefin tuna fishery. Nevertheless, in many of these communities like Favignana, the tonnara was the principal fishery

15 Data reported is the most recent available from the National Institute for Italian Statistics. 
and major source of employment activity that, while seasonal, played a fundamental role in social organization (Lentini 1995). The demise of the traditional fishery in communities like these has had visible impacts on the ecology and social life, including the rapid crash of bluefin stocks and the loss of an important source of employment and cultural life.

\section{CONCLUSION}

Utilizing a political economic lens, this paper highlights the social and ecological impacts in the Mediterranean bluefin tuna fishery in the modern era. The modern system of bluefin tuna production has become an industrialized process that uses high levels of new technology, capital, and energy to produce a global commodity for luxury food markets. The treadmill of production theory along with a world-systems approach are drawn on to emphasize the ways in which production has been transformed within an expansionary economic system that has been historically founded on exploitation of humans and natural systems by powerful interests.

Bluefin tuna hailing from the Mediterranean have become a status symbol in core nations, particularly Japan, where relatively recent social phenomenon have created a high exchange value for a species that was, in many parts of the world, previously little regarded and valued. Transnational corporations provide this valuable commodity to upper and middle class consumers using new methods of production that intensify capture efforts. The market has become increasingly lucrative such that efforts were made to control production and add value to bluefin by fattening them in cages, what is commonly called tuna ranching.

The social and ecological consequences related to the transformations in extractive technologies have been intimately tied to globalized production and consumption in the modern capitalist world-system (Bunker and Ciccantell 2005). While TNCs have benefitted from the social and technological transformations in the modern bluefin fishery, there is a great deal of concern regarding the environmental impacts and social costs related to industrial fishing and rearing operations. Other resource users, particularly traditional trap fishers, have been negatively affected by industrial operations. In Sicily, these methods are all but extinct. Furthermore, the environmental degradation associated with tuna ranching has caused great alarm. Overfishing and other environmental concerns related to industrial capitalist ABFT production creates conditions that have serious ecological repercussions for ocean ecosystems and the communities linked to them. Thus, modern global political economic forces are having profound impacts on local populations and the environment.

\section{ACKNOWLEDGEMENTS}

The author would like to thank Jeannette Longo, the many individuals in Sicily that assisted in this research, and the reviewers and the editors at the Journal of World Systems Research. 
GLOBAL SUSHI 422

\section{REFERENCES}

Addis, Piero, John Mark Dean, Paola Pesci, Ivan Locci, Rita Cannas, Stefano Corrias and Angelo Cau. 2008. "Effects of Local Scale Perturbations in the Atlantic Bluefin Tuna (Thunnus thynnus L.) Trap Fishery of Sardinia (W. Mediterranean)." Fisheries Research 92:242254.

ATRT. 2006. The Plunder of the Bluefin in the Mediterranean and the East Atlantic in 2004 and 2005. Uncovering the Real Story: The Collapse of Fisheries Management. Retrieved February 1 , 2008 (http://assets.panda.org/downloads/wwfbftreportfinaleditionreducido_final.pdf). . 2008. Race for the Last Bluefin: Capacity of the Purse Seine Fleet Targeting Bluefin Tuna in the Mediterranean Sea and Estimated Capacity Reduction Needs. Retrieved November 30 , 2008 (http://wwf.panda.org/what_we_do/where_we_work/mediterranean/publications/?uNews $\mathrm{ID}=126820)$.

Bailey, Connor. 1985. "The Blue Revolution: The Impact of Technological Innovation on Third World Fisheries." The Rural Sociologist 5:259-66.

Bailey, Connor, Svein Jentoft, and Peter Sinclair. 1996. Aquacultural Development: Social Dimensions of an Emerging Industry. Boulder, CO: Westview Press.

Balaam, David N., and Michael Veseth. 2007. Introduction to International Political Economy. Upper Saddle River, NJ: Pearson/Prentice Hall.

Bestor, Theodore C. 2001. "Supply-Side Sushi: Commodity, Market, and the Global City." American Anthropologist 103:76-95. . 2004. Tsukiji: The Fish Market at the Center of the World. Berkeley, CA: University of California Press.

Bonanno, Alessandro, and Douglas H. Constance. 1996. Caught in the Net: The Global Tuna Industry, Environmentalism and the State. Lawrence, KS: University Press of Kansas.

Bregazzi, Roberto M. 2005. The Tuna Ranching Intelligence Unit. Retrieved February 1, 2008 (http://assets.panda.org/downloads/thetunaranchingintelligenceunit2004.pdf). . 2006. Thunnus Nostrum: Bluefin Tuna Fishing \& Ranching in the Mediterranean Sea 2004 - 2005. Madrid, Spain: Advanced Tuna Ranching Technologies.

Burros, Marian. 2008. "High Mercury Levels Are Found in Tuna Sushi." New York Times, $\begin{array}{lllll}\text { January } & 23 . & \text { Retrieved } & \text { January } & 31,\end{array}$ (http://www.nytimes.com/2008/01/23/dining/23sushi.html).

Buttel, Frederick H. 1987. "New Directions in Environmental Sociology." Annual Review of Sociology 13:465-488.

. 2002. "Environmental Sociology and the Classical Sociological Tradition: Some Observations on Current Controversies." Pp. 35-50 in Sociological Theory and the Environment: Classical Foundations, Contemporary Insights, edited by Riley E. Dunlap, Frederick H. Buttel, Peter Dickens and August Gijswijt. New York: Rowman \& Littlefield.

Bunker, Stephen G. 1984. "Modes of Extraction, Unequal Exchange, and the Progressive Underdevelopment of an Extreme Periphery: The Brazilian Amazon, 1600-1980." American Journal of Sociology 89:1017-1064. 
Bunker, Stephen G. and Paul S. Ciccantell. 2005. Globalization and the Race for Resources. Baltimore, MD: John Hopkins University Press.

Consolo, Vincenzo. 1986. La Pesca del Tonno in Sicilia. Palermo, Italy: Sellerio Editore.

Comune di Favignana. 2008. Servizi Demografici. Favignana, Italy: Ufficiale d'Anagrafe.

Crescimanno, Maria, and Anna M. Di Trapani. 2007. Pesca e Allevamento del Tonno Rosso Mediterraneo. Palermo, Italy: Università degli Studi di Palermo.

D'Amico, Francesco C. 1816. Osservazioni Pratiche Intorno alla Pesca, Corso e Camino dei Tonni. Messina, Italy: Presso la Societá Tipografica.

Di Trapani, Anna M. 2007. "Il Mercato del Tonno Rosso." Pp. 57-75 in Pesca e Allevamento del Tonno Rosso Mediterraneo, edited by Maria Crescimanno and Anna Maria Di Trapani. Palermo, Italy: Università degli Studi di Palermo.

Duncan, Emma, and Justin Woolford. 2006. Fish Dish: Exposing the Unacceptable Face of Seafood. Gland, Switzerland: WWF International. Retrieved January 30, 2008. (http://www.wwf.dk/dk/Service/Bibliotek/Hav+og+fiskeri/Rapporter+mv./fishdishreportf inal150906_v1fv.pdf).

Ellis, Richard. 2003. "The Magnificent Bluefin." Ecologist 33:44-45. . 2008. Tuna: A Love Story. New York: Alfred A. Knopf.

Foster, John Bellamy. 1999. "Marx's Theory of Metabolic Rift: Classical Foundations for Environmental Sociology." American Journal of Sociology 105:366-405.

Friedland, William H. 2004. "Agrifood Globalization and Commodity Systems." International Journal of Sociology of Agriculture and Food 12:17-28.

Friedman, Harriet. 1982. "The Political Economy of Food: The Rise and Fall of the Postwar International Food Order." American Journal of Sociology 88:248-286.

Fuentes Group. 2007. "Ricardo Fuentes e Hijos." Retrieved November 17, 2007 (http://www.ricardofuentes.com).

Garcia, Serge M. and Christopher Newton. 1997. "Current Situation, Trends, and Prospects in World Capture Fisheries." Pp. 3-27 in Global Trends: Fisheries Management, edited by Ellen K. Pikitch, Daniel D. Huppert and Michael P. Sissenwine. Bethesda, MD: American Fisheries Society.

Gaski, Andrea L. 1993. An Examination of the International Trade in Bluefin with an Emphasis on the Japanese Market. Cambridge, MA: TRAFFIC International.

Gellert, Paul K. and Shefner, Jon. 2009. "People, Place, and Time: How Structural Fieldwork Helps Word-Systems Analysis.” Journal of World Systems Research XV:193-218.

Ginsborg, Paul. 2003. A History of Contemporary Italy: Society and Politics 1943 -1988. New York: Palgrave Macmillan.

Goodman, David. 1991. "Some Recent Tendencies in the Industrial Reorganization of the AgriFood System." Pp. 37-64 in Towards a New Political Economy of Agriculture, edited by William H. Friedland, Lawrence Busch, Frederick H. Buttel and Alan P. Rudy. Boulder, CO: Westview Press.

Grimes, Peter and Jeffrey Kentor. 2003. "Exporting the Greenhouse: Foreign Capital Penetration and CO2 Emissions 1980-1996." Journal of World-Systems Research 9:261-275.

IAM. 1998. Map of the Mediterranean Basin. Chapel Hill, NC: Interactive Ancient Mediterranean.

ICCAT. 2007a. Management Recommendations and Resolutions Adopted by ICCAT for the Conservations of Atlantic Tunas and Tuna-Like Species. Madrid, Spain: International 
Commission for the Conservation of Atlantic Tuna. Retrieved November 21, 2009 (http://www.iccat.int/en/RecsRegs.asp).

2007b. Recommendations by ICCAT Concerning a Multi-Year Conservation and Management Plan for Bluefin Tuna in the East Atlantic and Mediterranean. Madrid, Spain: International Commission for the Conservation of Atlantic Tuna. Retrieved November 21, 2009 (http://www.iccat.int/en/RecsRegs.asp).

.2007c. Report of the Standing Committee on Research and Statistics (SCRS). Madrid, Spain: International Commission for the Conservation of Atlantic Tuna. Retrieved November 21, 2008 (http://www.iccat.int/en/SCRS.htm)

. 2008. ICCAT Record of BFT Farming Facilities. Retrieved December 30, 2008 (http://www.iccat.int/en/ffb.asp).

Issenberg, Sasha. 2007. The Sushi Economy: Globalization and the Making of a Modern Delicacy. New York: Gotham Books.

ISTAT. 2010. "Inidcatore Territoriale." ISTAT, Istituto Nazionale di Statistica. Retrieved March 13, 2010 (http://www.istat.it).

Jackson, Jeremy B.C. Michael X. Kirby, Wolfgang H. Berger, Karen A. Bjorndal, Louis W. Botsford, Bruce J. Bourque, Roger H. Bradbury, Richard Cooke, Jon Erlandson, James A. Estes, Terence P. Hughes, Susan Kidwell, Carina B. Lange, Hunter S. Lenihan, John M. Pandolfi, Charles H. Peterson, Robert S. Steneck, Mia J. Tegner, and Robert R. Warner 2001. "Historical Overfishing and the Recent Collapse of Coastal Ecosystems." Science 293:629-638.

Jorgenson, Andrew. 2003. "Consumption and Environmental Degradation: A Cross-National Analysis of the Ecological Footprint." Social Problems 50:374-394.

La Mantia, Vito. 1901. Le Tonnare in Sicilia. Palermo, Italy: Tipografia Giannitrapani.

Lentini, Rosario. 1995. "Favignana e la Sua Tonnara." Pp. 19-22 in Tonnara, edited by G. Martorana. Palermo: Sellerio.

Magdoff, Fred, John B. Foster, and Frederick Buttel. 2000. Hungry for Profit: The Agribusiness Threat to Farmers, Food, and the Environment. New York: Monthly Review Press.

Mather, Frank J, John M. Mason, and A. C. Jones. 1995. Historical Document: Life History and Fisheries of Atlantic Bluefin Tuna. Springfield, VA: Southeast Fisheries Science Center.

McMichael, Philip. 1995. Food and Agrarian Orders in the World-Economy. Westport, CT: Greenwood Press.

Mintz, Sidney W. 1985. Sugar and Power: The Place of Sugar in Modern History. New York: Viking.

Mitsubishi Corporation. 2007a. "Mitsubishi." Retrieved on September 21, 2007. (http://www.mitsubishicorp.com). . 2007b. Statement of Consolidated Income for the Years Ended March 31, 2007 and 2006 and Consolidated Balance Sheet of March 31, 2007. Tokyo, Japan: Mitsubishi Corporation.

Mitsui and Company. 2007. Consolidated Financial Results for the Year Ended March 31, 2007. Tokyo, Japan: Mitsui and Company Ltd.

Miyabe, Naozumi. 2003. "Description of the Japanese Long-Line Fishery and its Fishery Statistics in the Mediterranean Sea During the Recent Years" ICCAT Collective Volume of Scientific Papers 55(1):131-137. Retrieved January 28, 2008 (http://www.iccat.int/en/pubs_CVSP.htm). 
Miyake, Peter M., José M. De la Serna, Antonio. Di Natale, Andreina Farrugia, Ivan Katavic, Naozumi Miyabe, and Vjekoslav Ticina 2003. "General Review of Bluefin Tuna Farming in the Mediterranean Area." ICCAT Collective Volume of Scientific Papers 55(1):114124. Retrieved January 28, 2008 (http://www.iccat.int/en/pubs_CVSP.htm).

Moore, Jason W. 2003. "The Modern World-System as Environmental History? Ecology and the Rise of Capitalism." Theory and Society 32: 307-377.

Myers, Ransom A. and Borris Worm. 2003. "Rapid Worldwide Depletion of Predatory Fishing Communities." Nature 423:280-283.

Naylor, Rosamond L., Rebecca J. Goldburg, Harold Mooney, Malcolm C. M. Beveridge, Jason Clay, Carl Folke, Nils Kautsky, Jane Lubchenco, Jurgenne H. Primavera, and Meryl Williams. 1998. "Nature's Subsidies to Shrimp and Salmon Farming." Science 282:883884.

Naylor, Rosamond L., Rebecca J. Goldburg, Jurgenne H. Primavera, Nils Kautsky, Malcolm C. M. Beveridge, Jason Clay, Carl Folke, Jane Lubchenco, Harold Mooney, and Max Troell. 2000. "Effect of Aquaculture on World Fish Supplies." Nature 405:1017-1024.

NOAA. 2010. "Japanese Fishery Imports." NOAA Southwest Regional Office, National Marine $\begin{array}{lllll}\text { Fisheries } & \text { Service. } & \text { Retrieved } & \text { March } & 18,\end{array}$ (http://swr.nmfs.noaa.gov/fmd/sunee/imports/jimp.htm).

O'Connor, James. 1991. "On the Two Contradictions of Capitalism." Capitalism, Nature, Socialism 2:107-109.

Ottolenghi, Francesca. 2008. "Capture Based Aquaculture of Bluefin Tuna." Pp. 169-182 in Capture-Based Aquaculture: Global Overview. FAO Fisheries Technical Paper No. 508, edited by A. Lovatelli and P.F. Holthus. Rome, Italy: Food and Agriculture Organization of the United Nations.

Ottolenghi, Francesca, Cecilia Silvestri, Paola Giordano, Alessandro Lovatelli, and Michael B. New. 2004. Capture-Based Aquaculture: The Fattening of Eels, Groupers, Tunas, and Yellowtails. Rome, Italy: Food and Agriculture Organization of the United Nations.

Pauly, Daniel, Villy Christensen, Sylvie Guénette, Tony J. Pitcher, U. Rashid Sumaila, John A. Smith, R. Watson, and Dirk Zeller. 2002. "Towards Sustainability in World Fisheries." Nature 418:689-695.

Pauly, Daniel, Villy Christensen, Johanne Dalsgaard, Rainer Froese, and Francisco Torres. 1998. "Fishing Down Marine Food Webs." Science 279:860-863.

Pauly, Daniel. 2004. "Empty Nets." Alternative Journal 30:8-13.

Pope, Frank. 2009. "'Hypocritical' EU Gives $€ 34.5 \mathrm{M}$ to Fleets Fishing Tuna to Extinction." The Times Online, December 4. Retrieved December 5, 2009 (www.timesonline.co.uk/tol/news/environment/article6943367.ece).

Roberts, Timmons and Peter Grimes 2002. "World-System Theory and the Environment: Toward a New Synthesis." Pp. 167-194 in Sociological Theory and the Environment: Classical Foundations, Contemporary Insights, edited by Riley E. Dunlap, Frederick H. Buttel, Peter Dickens and August Gijswijt. New York: Rowman \& Littlefield.

Safina, Carl. 1996. "Thunnus Thynnus (Eastern Atlantic Stock)." Gland, Switzerland: International Union for Conservation of Nature and Natural Resources. Retrieved December 10, 2008 (www.iucnredlist.org).

. 1998. Song for the Blue Ocean: Encounters Along the World's Coasts and Beneath the Seas. New York: Henry Holt. 
2001. "Tuna Conservation." Pp. 414-457 in Tuna: Physiology, Ecology, and Evolution, edited by Barbara A. Block and E. Donald Stevens. New York: Academic Press. . 2003. "Tuna Fisheries Around the World." The Ecologist 33:47.

Safina, Carl, and Dane H. Klinger. 2008. "Collapse of Bluefin Tuna in the Western Atlantic." Conservation Biology 22:243-246.

Sarà, Raimondo. 1998. Dal Mito all' Aliscafo: Storie di Tonni e di Tonnare . Messina, Italy: Editore Raimondo Sará.

Sawada, Yoshifumi, Tokihiko Okada, Shigeru Miyashita, Osamu Murata, and Hidemi Kumai. 2005. "Completion of the Pacific Bluefin Tuna Thunnus Orientalis (Temminck Et Schlegel) Life Cycle." Aquaculture Research 36:413-421.

Schaeffer, Kurt M. 2001. "Reproductive Biology of Tunas." Pp. 225-247 in Tuna Physiology, Ecology and Evolution edited by Barbara A. Block and E. Donald Stevens. New York: Academic Press.

Schnaiberg, Allan. 1980. The Environment, From Surplus to Scarcity. New York: Oxford University Press.

Schnaiberg, Allan and Kenneth A. Gould. 1994. Environment and Society: The Enduring Conflict. New York: St. Martin's Press.

Tudela, Sergi, and Raúl García. 2004. Tuna Farming in the Mediterranean: The Bluefin Tuna Stock at Stake. Rome, Italy: WWF Mediterranean Program Office. Retrieved March 5, 2007

(http://wwf.panda.org/what_we_do/where_we_work/mediterranean/publications/?13510/

Tuna-Farming-in-the-Mediterranean-the-bluefin-tuna-stock-at-stake).

UN FAO. 2004. Management of Tuna Fishing Capacity: Conservation and Socioeconomics. Madrid, Spain: Food and Agriculture Organization of the United Nations. Retrieved April 23, 2008 (ftp://ftp.fao.org/docrep/fao/008/y5984e/y5984e00.pdf).

. 2007. The State of the World's Fisheries and Aquaculture, 2006. Rome, Italy: Food and Agriculture Organization of the United Nations. Retrieved April 23, 2008 (http://www.fao.org/docrep/009/a0699e/a0699e00.HTM).

. 2008. "FAO Fisheries and Aquaculture - Geartype Fact Sheets." Rome, Italy: Food and Agriculture Organization of the United Nations. Retrieved April 23, 2008 (www.fao.org/fishery/geartype/249).

. 2010. Fisheries and Aquaculture Information and Statistics Service. Rome, Italy: Food and Agriculture Organization of the United Nations. Retrieved February 3, 2010 (http://www.fao.org/fishery/en).

Villabianca, (Marchese di) F.F.e.G. [1764] 1986. Le Tonnare della Sicilia. Palermo: Edizione Giada.

Volpe, John P. 2005. "Dollars Without Sense: The Bait for Big-Money Tuna Ranching Around the World." Bioscience 44:301-302.

Whynott, Douglas. 1995. Giant Bluefin. New York: Farrar Straus Giroux.

World Bank. 2004. Saving Fish and Fishers: Toward Sustainable and Equitable Governance of the Global Fishing Sector. Washington D.C: World Bank. .2006a. Aquaculture: Changing the Face of the Waters. Washington D.C.: World Bank. 2006b. World Development Indicators 2005. Washington D.C.: World Bank.

Worm, Boris, Edward B. Barbier, Nicola Beaumont, J. Emmett Duffy, Carl Folke, Benjamin S. Halpern, Jeremy B. C. Jackson, Heike K. Lotze, Fiorenza Micheli, Stephen R. Palumbi, 
Enric Sala, Kimberley A. Selkoe, John J. Stachowicz, and Reg Watson. 2006. "Impacts of Biodiversity Loss on Ocean Ecosystem Services." Science 314:787-790.

Wright, Hillel. 2009. "What Future for Fish As Japan's Daily Fare?" The Japan Times Online Jan 25. Retrieved January 25, $2009 \quad$ (http://search.japantimes.co.jp/cgibin/fl20090125x1.html).

WWF. 2002. Tuna at Risk in Mediterranean Gold Rush. Madrid, Spain: WWF - World Wildlife $\begin{array}{llll}\text { Fund for Nature. Retrieved June } 2007 & \end{array}$ (http://www.panda.org/what_we_do/where_we_work/mediterranean/news/?4686/Tunaat-risk-in-Mediterranean-gold-rush).

. 2006. On the Brink of Collapse: Mediterranean Bluefin Tuna, the Consequences of Collapse. Gland, Switzerland: WWF International - Global Marine Programme. Retrieved April 20 , 2008 (http://www.wwf.or.jp/activities/lib/pdf/onthebrinktunacollapse.pdf).

—. 2008. "Bluefin Tuna in Crisis." Retrieved October 2, 2008 (http://www.panda.org/tuna).

York, Richard, and Marcia Hill Gossard. 2004. "Cross-National Meat and Fish Consumption: Exploring the Effects of Modernization and Ecological Context." Ecological Economics 48:293-302.

York, Richard, Eugene Rosa, and Thomas Dietz. 2003. "Footprints on the Earth: The Environmental Consequences of Modernity." American Sociological Review 68:279-300. 